\title{
PERUBAHAN PARADIGMA DALAM ORGANISASI BELAJAR DI ABAD 21
}

\author{
M. Fakhruddin, Rusydi Ananda, \& Siti Istiningsih \\ e-mail: rusdiananda.1972@gmail.com \\ Program Pascasarjana Universitas Negeri Jakarta
}

\begin{abstract}
Abstrak: Kemajuan ilmu pengetahuan dan teknologi yang begitu cepat dalam abad 20 dan awal abad 21 mendorong cara manusia berpikir dan bertindak ikut berubah. Masyarakat atau bangsa yang tidak menyesuaikan diri dengan perubahan yang terjadi akan tertinggal dan terisolasi. Sebagai dampak perubahan yang begitu radikal, pengelolaan organisasi sosial dan organisasi komersial dituntut pula ikut berubah dan belajar terus menerus. Masalahnya ialah bagaimana organisasi harus dikelola dengan menggunakan paradigm baru di abad 21 ini. Tulisan ini membahas perubahan paradigma di abad 21 ini sebagai akibat perkembangan ilmu pengetahuan dan teknologi yang antara lain mengakibatkan batas-batas antar negara dan budaya semakin tidak jelas sehingga memperluas dan memperkuat globalisasi berbagai aspek kehidupan manusia. Pembahasan secara induktif dan deduktif diarahkan pada organisasi pendidikan dengan kesimpulan bahwa lembaga pendidikan juga perlu peka terhadap peruhahan yang terjadi di sekitarnya termasuk di seluruh dunia serta melakukan penyesuaian dalam pengelolaan dan kepemimpinan dengan menerapkan prinsip-prinsip organisasi belajar.
\end{abstract}

Kata kunci: paradigma, globalisasi, organisasi belajar, kepeimpinan

\section{PARADIGM SHIFT IN LEARNING ORGANIZATION IN THE TWENTIETH CENTURY}

\begin{abstract}
Abstrak:Abstract. The fast development of advance science and technology in the twentieth century has forced the people to change and adjust their ways of thinking and acting. Any society or nation does not adjust themselves to the changes around them will be left behind and isolated. As the effect of the radical changes, the social and commercial organizations are demanded to change to be able to survive and develop. The problem is how to manage and lead the organizations properly applying the new paradigm of the twentieth century. This article critically discusses the paradigm shift in the twentieth century resulted by the fast development of science and technology and in the other side it brought some problems such as borderless nations or globalization. The deductive and inductive analysis of the problems in this article concludes that educational organizations in particular should be proactive and absorb the positive changes occurring in their environment and in the world. Management and leadership within the educational institution should be based on the learning organization principles to survive, develop, and compete.
\end{abstract}

Keywords: paradigm, globalization, learning organization, leadership.

\section{PENDAHULUAN}

Istilah paradigma pertama kali diperkenalkan oleh Kuhn (1962), dan kemudian dipopulerkan oleh Friedrichs (1970). Paradigma adalah cara mengetahui realitas sosial yang dikonstruksi oleh mode of thought atau mode of inquiry tertentu, yang kemudian menghasilkan mode of knowing yang spesifik (Kuhn: 1962). Definisi tersebut dipertegas oleh Friedrichs, sebagai suatu pandangan yang mendasar dari suatu disiplin ilmu tentang apa yang menjadi pokok persoalan yang semestinya dipelajari. Dengan demikian dapatlah dipahami bahwa paradigma sebagai pandangan yang mendasar dari para ilmuan tentang apa yang menjadi pokok persoalan yang semestinya dipelajari oleh salah satu cabang/disiplin ilmu pengetahuan.

Paradigma dibagi menjadi tiga elemen yang meliputi; epistemologi, ontologi, dan metodologi (Denzin \& Lincoln: 1994). Epistemologi mempertanyakan tentang bagimana cara kita mengetahui sesuatu. Ontologi berkaitan dengan pertanyaan dasar tentang hakikat realitas. Metodologi memfokuskan pada bagaimana cara kita memperoleh pengetahuan. Posisi paradigma sebagai alat bantu bagi ilmuwan untuk merumuskan berbagai hal yang 
berkaitan dengan: (1) apa yang harus dipelajari, (2) persoalan-persoalan apa yang harus dijawab, (3) bagaimana metode untuk menjawabnya, dan (4) aturan-aturan apa yang harus diikuti dalam menginterpretasikan informasi yang diperoleh (Zamroni: 1992).

Perkembangan ilmu tidak selalu berjalan linear, karena itu tidak benar kalau dikatakan perkembangan ilmu itu bersifat kumulatif (Kuhn: 1962). Penolakan Kuhn didasarkan pada hasil analisisnya terhadap perkembangan ilmu itu sendiri yang ternyata sangat berkait dengan dominasi paradigma keilmuan yang muncul pada periode tertentu. Bahkan bisa terjadi dalam satu waktu, beberapa metode pengetahuan berkembang bersamaan dan masing-masing mengembangkan disiplin keilmuan yang sama dengan paradigma yang berlainan. Perbedaan paradigma dalam mengembangkan pengetahuan, menurut Kuhn, akan melahirkan pengetahuan yang berbeda pula. Sebab bila cara berpikir (mode of thought) para ilmuwan berbeda satu sama lain dalam menangkap suatu realitas, maka dengan sendirinya pemahaman mereka tentang realitas itu juga menjadi beragam. Konsekuensi terjauh dari perbedaan mode of thought ini adalah munculnya keragaman skema konseptual pengembangan pengetahuan yang kemudian berakibat pula pada keragaman teori-teori yang dihasilkan.

Makalah ini ingin mendeskripsikan tentang paradigma baru dalam abad 21 dengan uraian yang difokuskan mengenai karakteristik abad 21, organisasi abad 21 dan organisasi belajar yang bersumber dari berbagai rangkuman literatur yang relevan.

\section{PEMBAHASAN}

\section{Karakteristik Abad 21}

Menjalani abad 21 yang memasuki tahun ke-13, begitu banyak perubahan yang fundamental dalam berbagai aspek kehidupan manusia. Dunia seakan tanpa batas geografis dan waktu serta berubah menjadi hunian besar di mana orang-orangnya dengan mudah saling berinteraksi, berkomunikasi, dan bertransaksi kapan saja, dari dan di manapun mereka berada.

Beberapa fenomena yang terjadi di abad 21 adalah era globalisasi yang ditandai antara lain: mengalirnya beragam sumber daya fisik maupun nonfisik (data, informasi, dan pengetahuan), meningkatnya kolaborasi dan kerjasama antar negara dalam proses penciptaan produk dan/atau jasa yang berdaya saing tinggi, menguatnya tekanan negara-negara maju terhadap negara berkembang; membanjirnya produk-produk dan jasa-jasa negara luar yang dipasarkan di dalam negeri, bertambahnya tenaga asing seccara pesat dari level buruh hingga eksekutif memasuki bursa tenaga kerja nasional, dan meleburnya portofolio kepemilikan perusahaanperusahaan swasta menjadi milik bersama pengusaha Indonesia dan pihak asing.

Seiring dengan perkembangan tersebut, maka masalah yang dihadapi pada abad 21 juga semakin kompleks, saling memiliki terkaitan satu sama lain, cepat berubah dan penuh paradoks. Umumnya kaum futuris mengkaitkan pertumbuhan penduduk dunia yang bergerak secara cepat sebagai pemicu, apabila pada tahun 2010 penduduk dunia sebesar 6.9 milyar, maka pada tahun 2050 oleh United Nations Population Division diperkirakan mencapai 9.2 milyar orang, ini berarti dalam masa empat puluh tahun akan terjadi pertambahan sebesar 2.5 milyar penduduk. Dampak dari pertumbuhan ini pada seluruh kehidupan manusia luar biasa, mulai dari masalah kelangsungan hidup, pangan, kesehatan, kesejahteraan, keamanan, dan pendidikan.

Selanjutnya ciri yang menonjol pada abad 21 adalah semakin bertautnya dunia ilmu pengetahuan, sehingga sinergi diantaranya menjadi semakin cepat. Dalam konteks pemanfaatan teknologi informasi dan komunikasi di dunia pendidikan, telah terbukti semakin menyempitnya dan meleburnya faktor "ruang dan waktu" yang selama ini menjadi aspek penentu kecepatan dan keberhasilan penguasaan ilmu pengetahuan oleh umat manusia.

Abad 21 ditandai oleh arus globalisasi dan perkembangan teknologi informasi yang sangat cepat dan pesat (Teffler: 1992). Sejalan dengan itu, kemajuan teknologi itu menyebabkan sebagian besar tenaga manusia digantikan oleh mesin yang akan lebih banyak melakukan tugas rutin, sementara manusia akan lebih banyak bergelut dengan tugas-tugas yang bersifat intelektual dan kreatif. Seiring dengan itu, terjadi pula penghancuran nilai-nilai/harkat dan martabat manusia seperti penggunaan obat terlarang/ narkotika, kenakalan remaja, pergaulan bebas, serta pencemaran lingkungan akan meningkat. Dengan demikian, perubahan besar-besaran akan dan selalu terjadi, sehingga masa depan itu sebagai satu kejutan (future shock) terutama bagi komunitas yang lamban/ sulit berubah.

Karakteristik abad 21 yaitu: (1) integrasi kehidupan ekonomi dan fragmentasi kehidupan politik, (2) globalisasi, (3) perubahan secara radikal pasar tenaga kerja, (4) industrialisasi ekonomi dengan high technology, dan (5) lahirnya gaya hidup baru 
dengan ekses-ekses tertentu (Toffler: 1992).

Hal senada diungkapkan Badan Standar Nasional Pendidikan (2010) menjelaskan beberapa karakteristik abad 21 yaitu: (1) perhatian yang semakin besar terhadap masalah lingkungan hidup, berikut implikasinya terutama terhadap pemanasan global. energi, pangan, kesehatan, dan lingkungan; (2) dunia kehidupan akan semakin dihubungkan oleh teknologi informasi, berikut implikasinya terutama terhadap ketahanan dan sistim pertahanan, pendidikan, industri, dan komunikasi; (3) ilmu pengetahuan akan semakin converging, berikut implikasinya terutama terhadap penelitian, filsafat ilmu, paradigma pendidikan, dan kurikulum; (4) kebangkitan pusat ekonomi dibelahan Asia Timur dan Tenggara berikut implikasinya terhadap politik dan strategi ekonomi, industri, dan pertahanan; (5) perubahan dari ekonomi berbasis sumber daya alam serta manusia kearah ekonomi berbasis pengetahuan berikut dengan implikasinya terhadap kualitas sumber daya insani, pendidikan, dan lapangan kerja; (6) perhatian yang semakin besar pada industri kreatif dan industri budaya berikut implikasinya terutama terhadap kekayaan dan keanekaan ragam budaya, pendidikan kreatif, entrepreneurship, technopreneurship, dan rumah produksi; (7) budaya akan saling imbas mengimbas dengan teknosains berikut implikasinya terutama terhadap karakter, kepribadian, etika, hukum, kriminologi, dan media; (8) perubahan paradigma universitas, dari "Menara Gading" ke "Mesin Penggerak Ekonomi". Terdapat kecenderungan semakin meningkatnya investasi yang ditanamkan dari sektor publik ke perguruan tinggi untuk riset ilmu dasar dan terapan serta inovasi teknologi/desain yang memberikan dampak pada pengembangan industri dan pembangunan ekonomi dalam arti luas.

\section{Organisasi Abad 21}

Pada abad 21, organisasi akan tergantung pada 3 pilar utama yaitu (1) kepemimpinan, (2) proses, dan (3) organisasi (Chowdhury: 2005)

Pilar pertama yaitu kepemimpinan. Abad 21 menuntut paradigma baru tentang kepemimpinan yaitu pemimpin yang mampu membuat inovasi, melakukan terobosan-terobosan pengembangan, memberikan inspirasi dan memperluas pandangan ke depan, giat bertanya dan menantang sehingga mereka sungguh-sungguh melakukan hal-hal yang benar. Tugas pemimpin tidak lagi hanya sebatas merumuskan visi, membuat keputusan strategis, serta mengarahkan semua sumber daya untuk mewujudkan visi itu atau memberikan perintah lalu mengawasinya.

Urgensi kepemimpinan menganut prinsip- prinsip baru dalam organisasi dengan menyatakan bahwa kepemimpinan perlu meluas dan mendalam pada setiap fungsi serta diterapkan di seluruh lini organisasi (Humphrey dalam Shelton: 1997) . Apabila ingin berkembang dan mampu bersaing, organisasi hendaknya memberikan kepercayaan pada kepemimpinan personal yang dimiliki setiap individu di setiap lini. Dengan perkataan lain bahwa orgaisasi belajar membelajarkan setiap orang menjadi pemimpin dirinya sendiri dan pada waktunya nanti siap memimpin orang lain dan organisasi menghindari kepemimpinan berpusat kepada sesorang atau kelompok tertentu dalam organisasi.

Pemimpin abad 21 adalah pemimpin yang mampu melakukan pemberdayaan (Shelton: 1997). Pemberdayaan yang akan berfungsi dengan baik serta berhasil apabila pemimpin memberikan kepercayaan kepada orang-orang dalam organisasi dan melonggarkan pengawasan dan penilaian yang ketat atas kinerja mereka. Kepercayaan yang diberikan oleh pemimpin akan memotivasi mereka mengawasi dan mengendalikan dirinya sendiri serta menilai kinerjanya secara bertanggung jawab. Melalui pemberdayaan yang demikianlah akan memunculkan rasa kepemilikan (sense of belonging/ownership). Pemimpin membimbing dan memberikan bantuan tanpa menghilangkan tanggung jawab.

Pemimpin abad 21 setidaknya menjalankan dua peran utama yaitu: (1) peran karismatik meliputi: melakukan prediksi, melakukan pemberdayaan dan melakukan peningkatan daya kerja, dan (2) peran pembangun meliputi: mendesain organisasi, menyusun struktur, merumuskan sistem kontrol dan merumuskan sistem imbalan (Vries \& Treacy dalam Chowdury: 2005). Karakteristik pemimpin abad 21 yaitu: create a compelling vision, break down barriers, dan bust the bureaucracy (Shelton: 1997).

Berkaitan dengan kompetensi yang melekat pada diri pemimpin dalam menjalankan kepemimpinan di organisasi maka terdapat 18 kompetensi kepemimpinan yang dijelaskan (Spencer \& Kazanas, 1993) yaitu: (1) result orientation, (2) influence, (3) initiative, (4) flexibility, (5) concern for quality, (6) technical expertise, (7) analytical thinking, (8) conceptual thinking, (9) team work, (10) service orientation, (11) interpersonal awareness, (12) relationship building, (13) cross cultural sensitivity, (14) strategic thinking, (15) entrepreneurial orientation, (16) building organizational commitment, (17) empowering others, dan (18) developing others.

Strategi pengembangan kepemimpinan pada abad ke-21 agar tetap menjadi "champion" dijelaskan 
adalah: (1) menjadi rekan yang stratejik, (2) menjadi seorang pakar, (3) menjadi seorang pekerja ulung, dan (4) menjadi seorang "agent of change" (Ulrich: 1998).

Pilar kedua yaitu proses. Organisasi abad 21 dalam proses pengelola manajemennya fokus pada 4 (empat) kegiatan inti (core practices) yaitu: (1) grass root education, (2) fire prevention, (3) direct interaction, dan (4) effective globalization.

Grass root education adalah pendidikan dan pelatihan yang melibatkan seluruh staff tanpa diskriminasi, dari pimpinan sampai staf biasa. Fire prevention dimaksudkan sebagai wawasan dan upaya untuk meningkatkan kemanfaatan teknologi dalam produksi dan distribusi produk-produk tertentu. Direct interaction menekankan pada entusisme pelanggan di samping kepuasannya. Effective globalization adalah kecepatan memberi respons dalam menghadapi perubahan dramatik yang terjadi.

Manajemen organisasi pada hakikatnya berkaitan dengan "knowledgeworker" yang memerlukan paradigma manajemen baru, strategi baru, pemimpin perubahan, tantangan informasi, produktivitas pegawai berbasis pengetahuan, dan kemampuan mengelola diri sendiri (Drucker : 1999).

Pengelolaan manajemen organisasi abad 21 perlu menjalankan prinsip-prinsip, yaitu: (1) harmonisasi, (2) transparansi, (3) standarisasi, (4) pembiayaan, (5) memperluas jangkauan, (6) kenali hal yang diinginkan pelanggan, (7) analisis tabel, dan (8) melihat ke hulu (Champy dalam Chowdury: 2005).

Pilar ketiga yaitu organisasi. Organisasi abad 21 adalah organisasi yang komit terhadap kualitas sumber daya manusia (SDM) dan kualitas produk/ jasa serta organisasi yang mampu menjadi organisasi belajar bagi seluruh individu dalam organisasi tersebut. Organisasi belajar adalah tempat orang secara terus menerus memperluas kemampuan atau kapasitas guna menciptakan hasil yang benar-benar mereka inginkan, dimana pola-pola berpikir baru dipupuk dan dikeembangkan, aspirasi kelompok diberi kebebasan, dan dimana anggota-anggotanya secara terus menerus belajar mempelajari (learning to learn) sesuatu secara bersama (Senge: 1996).

Organisasi belajar merupakan organisasi yang belajar secara bersama-sama dengan sekuat tenaga dan terus menerus mentransformasikan diri untuk mengumpulkan, mengelola, dan menggunakan pengetahuan dengan lebih baik untuk keberhasilan organisasi (Marquardt: 2002). Organisasi memberdayakan orang di dalam dan di luar organisasi untuk belajar dengan memanfaatkan teknologi untuk memaksimalkan belajar dan berproduksi.
Dalam organisasi belajar terlihat: (1) perkembangan dan belajar sesorang dikaitkan dengan perkembangan dan belajar organisasi secara khusus dan terstruktur; (2) berfokus pada kreativitas dan adaptability; (3) semua regu merupakan bagian dari proses belajar dan bekerja; (4) jaringan kerja sangat penting dalam belajar dan menyelesaikan pekerjaan; (5) berpikir sistem adalah fundamental, (6) memiliki visi yang jelas di mana mereka berada dan ke mana tujuan mereka; dan (7) secara terus menerus melakukan transformasi dan berkembang (Moris dalam Marquardt: 2002).

Ciri organisasi belajar seperti yang dikemukan di atas menunjukkan, organisasi memiliki lingkungan, iklim, serta budaya yang tidak hanya mendorong orang dalam organisasi itu belajar secara perorangan dan bersama-sama, tetapi juga mempercepat proses belajar itu sendiri untuk meningkatkan kinerja organisasi. Belajar dan saling membelajarkan menjadi kebutuhan individu dan kelompok serta bukan menjadi beban karena mereka merasakan kepuasan sendiri dalam menikmati hasil belajar berupa pengetahuan atau keterampilan baru dan keberhasilan kerja mereka. Masing-masing orang menemukan kegembiraan, kebanggaan, dan tantangan dalam bekerja. Perubahan yang terjadi secara terus menerus sebagai hasil belajar membuat iklim organisasi semakin bergairah. Organisasi dapat dianggap sebagai sekelompok pekerja yang diberdayakan dan menghasilkan pengetahuan, produk, dan jasa baru.

Contoh-contoh organisasi yang tetap eksis dan survive melalui proses belajar yang dialaminya (Kasali: 2007). Pertama, Garuda Indonesia Airway (GIA), organisasi ini belajar dengan mempelajari cara bisnis organisasi maskapai penerbangan lainnya yang membanjiri pasar penerbangan dengan program tiket low price (harga murah). Memperhatikan keadaan pasar seperti ini maka semula GIA berada pada bisnis tiket high price yang menawarkan kenyamanan dan keselamatan dalam penerbangan membuat jalur bisnis penerbangan baru yang berorientasi pada low price melalui maskapai penerbangan Citilink.

Kedua, PT. Gudang Garam (industri rokok) semula ada pabrik yang terkenal dengan produksi rokok kreteknya. Organisasi ini belajar dengan mempelajari terjadinya pergeseran kecenderungan minat konsumen terhadap rokok yang semula menyukai jenis rokok kretek beralih menyukai rokok berjenis ringga yaitu rokok filter. PT. Gudang Garam bergerak cepat memahami kondisi konsumen ini dengan mengeluarkan produksi beragama rokok jenis filter. Dengan melakukan inovasi seperti ini PT. 
Gudang Garam sampai saat ini tetap eksis dan survive. Ketiga, PT. Sido Muncul (produksi jamu), organisasi yang selalu menjaga imagenya dihadapan konsumen yang menginginkan kualitas dan produksi yang bersih dan sehat. Belajar dari hal ini PT. Sido Muncul selalu menampilkan dalam layanan iklannya yang berkaitan dengan pemilihan bahan jamu yang berkualitas dan produksi yang hiegenis, di samping itu PT. Sido Muncul mengubah paradigma konsumen yang selama ini bentuk jamu itu serbuk dan pahit maka PT. Sido Muncul memproduksi jamu berbentuk cair dengan rasa mint dan madu.

Pilar keempat yaitu Lembaga Pendidikan Abad 21. Berkaitan dengan pembahasan mengenai paradigma organisasi pada abad 21 di atas, lembaga pendidikan (pendidikan dasar sampai pendidikan tinggi) sebagai suatu organisasi, maka lembaga pendidikan harus mampu pula melakukan berbagai perubahan yang signifikan dalam menjawab perkembangan zaman.

Berkaitan dengan pentingnya organisasi (lembaga pendidikan) untuk belajar dalam menghadapi kompetisi organisasi dalam era globalisasi dijelaskan yaitu: terdapat empat kekuatan yang akan mendorong sebuah organisasi harus terus berubah dengan melakukan aktivitas belajar yaitu: (1) perubahan bidang sosial-ekonomi, dan ilmu pengetahuan yang disebabkan oleh terjadinya globalisasi berakibat semakin ketatnya tingkat persaingan dalam bidang barang dan jasa; terjadinya tekanan pada aspek lingkungan dan ekologi seperti pemanasan global (global warning) dan perkembangan dalam bidang ilmu pengetahuan dan teknologi yang pesat; (2) perubahan pada aspek lingkungan kerja, sebagai akibat dari tuntutan penerapan teknologi informasi dan komunikasi, perubahan dalam struktur organisasi, adanya tuntutan untuk meningkatkan efektivitas dan efesiensi organisasi, ledakan jumlah pekerja magang dan keragaman dan mobilitas dunia kerja; (3) perubahan harapan pelanggan berkenaan dengan aspek harga, mutu, inovasi dari barang dan jasa yang ditawarkan oleh organisasi, serta waktu dan pelayanan yang diberikan organisasi; dan (4) perubahan harapan pekerja yang menuntut dimilikinya keahlian dan keterampilan yang lebih tinggi, diterapkannya berbagai peraturan kerja dalam organisasi, serta harapan-harapan yang menuntut manajer untuk terus memberi motivasi kepada karyawan dan memberi fasilitas yang diperlukan untuk melakukan pekerjaan (Marquardt: 2004).

Memperhatikan penjelasan di atas, maka orientasi pendidikan tidak lagi hanya ke masa lampau atau masa kini, tetapi lebih terfokus ke masa depan, karena individu masa depan akan menghadapi perubahan yang lebih cepat lagi daripada sekarang. Oleh karena itu, sasaran utama pendidikan haruslah diletakkan pada peningkatan kualitas yang meliput setiap aspek pendidikan seperti kualitas tenaga pendidik dan kependidikan, kualitas sarana dan prasarana, kualitas pelaksanaan pembelajaran, dan kualitas pengelolaan pendidikan.

Pada tataran aplikatif, suatu lembaga pendidikan untuk menjadi organisasi belajar abad 21 yaitu (BSNP: 2010). Pertama, Pemanfaatan teknologi pendidikan. Kemajuan teknologi informasi dan komunikasi merupakan salah satu penyebab dan pemicu perubahan dalam dunia pendidikan. Dengan ditemukan dan dikembangkannya internet sebagai jejaring raksasa yang menghubungkan milyaran pusatpusat data/informasi di seluruh dunia dan individu/ komunitas global telah merubah proses pencarian dan pengembangan ilmu dalam berbagai lembaga pendidikan.

Kedua, peran strategi guru/dosen dan peserta didik. Peran guru pun tidak lagi menjadi seorang "infomediary" karena sang peserta didik sudah dapat secara langsung mengakses sumber-sumber pengetahuan yang selama ini harus diseminasi atau didistribusikan oleh guru/dosen di kelas. Guru akan lebih berfungsi sebagai fasilitator, pelatih ("coach"), dan pendamping para siswa yang sedang mengalami proses pembelajaran. Bahkan secara ekstrim, tidak dapat disangkal lagi bahwa dalam sejumlah konteks, guru dan murid bersama-sama belajar dan menuntut ilmu melalui interaksi yang ada di antara keduanya ketika sedang membahas suatu materi tertentu.

Ketiga, metode pembelajaran kreatif. Model belajar yang menekankan pada ciri khas dan keberagaman karakteristik siswai perlu dikembangkan. Di samping itu, harus pula ditekankan model pembelajaran berbasis kerjasama antar individu tersebut untuk meningkatkan kompetensi interpersonal dan kehidupan sosialnya. Merupakan salah satu tugas utama guru untuk memastikan bahwa melalui mekanisme pembelajaran yang dikembangkan, setiap individu dapat mengembangkan seluruh potensi diri yang dimilikinya untuk menjadi manusia pembelajar yang berhasil.

Keempat, materi ajar yang kontekstual. Materi ajar mengalami sejumlah penyesuaian dari yang berbasis konten menjadi berorientasi pada konteks. Tantangan yang dihadapi dalam hal ini adalah mengubah pendekatan pola penyelenggaraan pembelajaran dari yang berorientasi pada diseminasi materi dari sebuah mata ajar menjadi pemahaman 
sebuah fenomena dipandang dari berbagai perspektif ilmu pengetahuan (multidisiplin atau ragam mata ajar).

Kelima, struktur kurikulum mandiri berbasis individu. Struktur kurikulum yang diterapkan pun harus dapat dicustomised (tailor made curriculum) sesuai dengan kebutuhan dan rencana atau agenda masing-masing individu. Mengembangkan kurikulum mandiri berbasis individu ini bukanlah pekerjaan yang mudah. Diperlukan suatu desain dan konsep yang matang serta terbukti efektif dalam implementasinya. Di samping itu perlu adanya sejumlah prasyarat atau prakondisi yang harus dipenuhi terlebih dahulu sebelum menerapkan struktur kurikulum seperti ini, antara lain: kesiapan fasilitas dan sarana prasarana, kematangan peserta ajar, infrastruktur dan suprastruktur manajemen institusi yang handal, konten pengetahuan yang lengkap, dan lain sebagainya.

Hal senada juga diungkapkan Agung (2012) berkaitan dengan faktor-faktor penting yang harus terpenuhi untuk menjadikan lembaga pendidikan sebagai organisasi belajar yaitu: (1) kepemimpinan, (2) budaya adaptif, (3) struktur berbasis tim, (4) strategi partisipatif, (5) pemberadyaan tenaga pendidik dan kependidikan, dan (6) keterbukaan informasi (Agung: 2012).

Pertama, kepemimpinan. Perubahan paradigma organisasi akan mengakibatkan perubahan kedudukan dan peran pemimpin dalam organsiasi belajar (Sitepu: 2010). Gaya dan tipe kepemimpinan yang berhasil diterapkan dalam organisasi tradisional belum tentu berhasil diterapkan pada kepemimpinan organisasi belajar. Lembaga pendidikan diharapkan menerapkan prinsip-prinsip kepemimpinan bersama untuk memaksimalkan sumber daya yang dimiliki dan mengembangkan kemampuan kepemimpinan pada diri setiap orang.

Pemimpin bertanggung jawab membangun lembaga pendidikan yang memungkinkan setiap orang mengembangkan kemampuannya memahami kompleksitas dan visi serta memperbaiki model mental. Singkatnya, pemimpin bertanggung jawab atas terjadinya proses belajar dalam organisasi. Dengan demikian, pemimpin berfungsi lebih sebagai perancang, guru, dan pelayan. Kesan bahwa pemimpin adalah pakar, penunjuk arah, dan pengendali berubah menjadi katalist, penyalur/pembagi informasi, dan koordinator. Kepemimpinan dalam organisasi pendidikan dilandaskan pada pendekatan kolegial yang kooperatif dan kolaboratif.

Kepala sekolah berperan sebagai individu yang membuat visi masa depan, koordinator, fasilitator, motivator dengan memberikan kepercayaan, wewenang dan kekuasaan kepada tenaga pendidik dan kependidikan untuk menjalankan kegiatan dalam bentuk tim kerja (team work). Tim kerja bertugas dan bertanggung jawab sepenuhnya untuk mengidentifikasi dan memecahkan permasalahan yang dihadapi dalam mencapai visi dan tujuan sekolah.

Kemauan dan kemampuan kepemimpinan kepala sekolah merupakan awal dari perubahan menuju organisasi belajar. Kepemimpinan adalah satu-satunya alat di mana organisasi dapat berubah menjadi sebuah organisasi belajar (Dahl dalam Agung: 2012). Pemimpin membangun hubungan kerja berdasarkan visi yang dibuat bersama dan membentuk kultur yang dapat membantu pencapaiannya. Pemimpin mendorong staf/bawahannya untuk melihat keseluruhan sistem, mendorong kerja tim, mempelopori perubahan dan memperluas kapasitas orang untuk membentuk dan mencapai masa depan.

Kepemimpinan kepala sekolah dalam organisasi belajar diukur melalui: (a) kemampuan sebagai agen perubahan/pembaharuan, (b) memiliki visi ke depan, (c) berani mengambil resiko untuk perubahan dan kemajuan organisasi, (d) mempercayai orang lain untuk mengerjakan tugas dalam bentuk tim kerja, (e) bertindak atas dasar sistem nilai dan bukan atas dasar kepentingan individu, (f) kemampuan menjalankan peran sebagai koordinator, fasilitator, konsultatif, pembimbing, supervisor, dan motivator, (g) meningkatkan kemampuan secara terus menerus sepanjang hayat, (h) memiliki kemampuan untuk menyelesaikan permasalahn dan konflik internal organisasi, (i) kemampuan melibatkan pihak di luar sekolah, (j) memiliki self awereness dan mampu mengendalikan emosi, k) memiliki kemampuan mengelola emosi atas perasaaan, (1) memiliki kemampuan self motivation baik bagi diri sendiri dan orang lain, (m) memiliki impulse control yaitu mampu mengendalikan naluri/insting atau ledakan-ledakan emosi diri, (n) memiliki people skill berupa kemampuan empati dan membina hubungan yang baik dan harmonis dengan orang lain berdasarkan prinsip kesetaraan (Agung: 2012).

Kedua, budaya adaftif. Budaya adaftif adalah serangkaian nilai-nilai inti atau dasar, keyakinan dan pengertian yang memiliki sifat adaptif yang kuat terhadap perubahan dan lingkungan. Sifat adaptif ini muncul disebabkan oleh sikap antisipatif dan responsif terhadap lingkungan dan perubahan yang terjadi, sehingga menuntut adanya perubahan dan peningkatan hasil secara terus menerus oleh 
organisasi.

Pengembangan organisasi belajar perlu memiliki budaya adaptif yang kuat dengan indikasi sebagai berikut: (a) visi bersama dalam organisasi berupa nilai yang disebarkan, ditanamkan dan rasa pemilikian yang kuat dari warga sekolah; (b) pengembangan sistem simbol penguatan visi; (c) penerapan iklim demokrasi, egaliter, transparans dan akuntabilitas; (d) penerapan norma atau aturan organisasi yang jelas dan sesuai dengan pengembangan organisasi pembelajar; (e) interaksi dan hubungan anggota organisasi dalam tim kerja yang harmonis dan mendukung perubahan dan pencapaian visi dan tujuan; (f) adanya semangat kerja anggota organisasi yang kuat untuk mencapai visi dan tujuan; (g) penerapan disiplin dalam menjalankan tugas; (h) kecermatan pelaksanaan pekerjaan dan tepat waktu; (i) penciptaan iklim lingkungan fisik dan sosial yang aman, nyaman dan menyenangkan untuk mendorong pembelajaran; dan (j) terciptanya iklim penghargaan terhadap penciptaan ide-ide baru dan prestasi kerja.

Ketiga, struktur berbasis tim. Lembaga pendidikan sebagai organisasi belajar berusaha untuk memecahkan struktur vertikal yang kaku, di mana pimpinan bukan lagi sebagai pembuat keputusan tunggal tetapi melibatkan bawahan/staf. Untuk mencapai visi dan tujuan sekolah lebih diarahkan kepada tim-tim kerja yang dibentuk dalam organisasi sekolah tersebut. Pekerjaan/aktivitas dilaksanakan tim-tim dari tenaga pendidik dan kependidikan dengan keterampilan berbeda yang merotasikan pekerjaan untuk menghasilkan keseluruhan produk atau jasa.

Aktivitas lembaga pendidikan memusatkan perhatiannya pada pemberdayaan manusia di dalam organisasinya dengan memberikan keyakinan kepada tenaga pendidik dan kependidikan untuk melaksanakan pekerjaannya dan menunjukkan performa kinerja terbaiknya. Dalam konteks lembaga pendidikan, struktur berbasis tim dapat diartikan sebagai pemberian wewenang dan kekuasaan terhadap tim kerja dengan mengacu pada kebutuhan dan kegiatan yang ada, baik dalam lingkup bagianbagian yang terdapat dalam sistem dan hirarki sekolah ataupun pada tim-tim bentukan yang didasarkan pada kriteria tertentu.

Keempat, strategi partisipatif. Strategi partisipatif berkaitan dengan upaya pelibatan stakeholder dalam mendukung kegiatan sekolah. Partisipasi stakeholder dapat berupa: (a) keikutsertaan menentukan kebijakan dan program sekolah; (b) keikutsertaan mengawasi pelaksanaan kebijakan dan program sekolah; (c) keaktifan dalam pertemuan rutin di sekolah; (d) keterlibatan dalam kegiatan ekstrakurikuler; (e) keikutsertaan mengawasi mutu sekolah; (f) keaktifan dalam pertemuan komite sekolah; (g) pengeluaran untuk pembiayaan pendidikan; (h) keterlibatan dalam pengembangan iklim sekolah; dan (i) partisipasi dalam pengembangan sarana dan prasarana sekolah.

Kelima, pemberdayaan pendidik dan tenaga kependidikan. Lembaga pendidikan sebagai organisasi belajar melakukan pemberdayaan terhadap tenaga pendidik dan kependidikan yang dimilikinya dengan memberikan kekuasaan, kebebasan, pengetahuan dan ketrampilan untuk membuat keputusan dan melaksanakan pekerjaannya secara efektif. Pelimpahan kekuasaan dapat direfleksikan dalam tim kerja, kualitas, perluasan kerja dan kelompok partisipasi, juga wewenang pembuatan keputusan, pelatihan dan informasi sehinga tenaga pendidik dan kependidikan dapat melakukan pekerjaan tanpa supervisi yang ketat.

Sehubungan dengan perubahan orientasi pendidikan yang berfokus ke masa depan, maka orientasi berpikir bagi para penyelenggara pendidikan hendaknya berubah dengan struktur lembaga pendidikan yang didesain sesuai dengan kebutuhan kekinian yaitu pendidik dan tenaga kependidikan harus diberi kesempatan untuk berperan lebih aktif dalam mengembangkan organisasi lembaga pendidikan. Selanjutnya untuk mempertajam posisi dan peran pendidikan dan tenaga kependidikan di samping harus memenuhi kualifikasi akademik, maka juga dituntut untuk memiliki kompetensi dan selalu berusaha secara mandiri dan terus menerus meningkatkan kompetensinya agar tugas tugas yang dilakukan mampu memenuhi harapan dan tuntutan kompetensi SDM abad 21. Dalam hal ini kompetensi SDM berdasarkan "21st Century Partnership Learning Framework", yaitu: (1) Critical-Thinking and ProblemSolving Skills yaitu kemampaun berpikir kritis dan pemecahan masalah, (2) Communication and Collaboration Skills yaitu kemampuan berkomunikasi dan bekerjasama, (3) Creativity and Innovation Skills yaitu kemampuan mencipta dan membaharui (4) Information and Communications Technology Literacy yaitu literasi teknologi informasi dan komunikasi, (5) Contextual Learning Skills yaitu kemampuan belajar kontekstual, (6) Information and Media Literacy Skills yaitu kemampuan informasi dan literasi media.

Tenaga pendidik dapat dibagi sebagai berikut: (1) guru sebagai pekerja profesional dengan tugas memberi layanan kepada masyarakat; (2) guru dipersyaratkan menguasai ilmu dan keterampilan 
spesialis; (3) ilmu dan keterampilan tersebut diperoleh dari pendidikan yang mendalam dan berkelanjutan (Tilaar: 1995). Di sisi lain, tugas-tugas guru yang bersifat profesional harus ditunjang oleh motivasi tinggi yang ditandai dengan kinerja yang terukur.

Keenam, keterbukaan informasi. Informasi pada lembaga pendidikan sebagai organisasi belajar haruslah bersifat transparan dan ketahui oleh seluruh warga sekolah. Untuk mengidentifikasi permasalahan dan kebutuhan yang dihadapi sekolah serta menemukan alternatif pemecahannya maka tim-tim kerja yang terdapat dalam sekolah haruslah mengetahui dan memahami segenap informasi yang dimiliki oleh sekolah mulai dari visi dan tujuan sekolah, data formal anggaran, pembiayaan aktivitas, dan sebagainya.

Keterbukaan dan sharing informasi dalam lembaga pendidikan merupakan hal yang vital karena tim-tim kerja di dalamnya bekerja dengan ide-ide dan informasi tersebut. Apabila warga lembaga pendidikan tidak memiliki akses informasi secara benar dan total, maka cenderung terjadi prilaku aktivitas dan pelaksanaan pekerjaan yang menebak-nebak. Penuh kecurigaan, dan pada akhirnya membahayakan keberlangsungan program kerja yang disusunnya mengarah pada kegagalan. Lembaga pendidikan hendaknya mampu mengembangkan lembaganya sebagai organisasi belajar dengan cara membuka segenap informasi yang dimiliki sekolah. Dalam hal ini kepala sekolah memberikan akses informasi yang dibutuhkan warga sekolah serta melimpahkan wewenang penggunaannya. Hal ini sesuai dengan paradigma baru organisasi yang menekankan tranparansi dan keterbukaan informasi.

\section{PENUTUP}

\section{Kesimpulan}

Berdasarkan uraian di atas terlihat bahwa perkembangan yang signifikan cepatnya pada abad 21 dalam segala aspek kehidupan, termasuk dalam organisasi pendidikan. Tuntutan terhadap perubahan semakin kuat, oleh karena itu penguaaan atas berbagai kompetensi menjadi semakin urgen, kemampuan ber- pikir kritis, memecahkan masalah, dan berkolaborasi menjadi begitu dominan dalam kehidupan abad 21 .

Organisasi pendidikan dituntut mampu menyiapkan generasi dalam menjalani abad 21 melalui penerapan sistem manajemen lembaga pendidikan modern yaitu semua unsur-unsur yang terkait penyelenggaraan pendidikan dapat dikelola dengan tepat dan sesuai dengan tuntutan kekinian. Prinsip kepemimpinan yang kuat, penuh kreatif dan inovatif, serta didukung dengan pelaksanaan program yang sistematis dan pertanggungjawaban yang tinggi akan mendukung suksesnya penyelenggaraan pendidikan.

\section{DAFTAR PUSTAKA}

Chowdhury, S. (ed). (2005). Organisasi Abad 21. Alihbahasa: Ati Cahayani. Jakarta: Indeks

Denzin, N., \& Lincoln, Y.S. (1994). Handbook of Qualitative Research Thousand Oaks: SAGE Publications

http://mebermutu.org/media2.php?module=detailknowledge\&id $=40$

Kasali, R. (2007). Change. Jakarta: Gramedia

Marquardt, M.J., \& Reynolds, A. (1994). The global learning organization. New York: Irwin

Marquardt, M.J. (2002). Building the learning organization. Mastering the 5 element for corporate learning. 2Nd edition. Palo Alto, CA: Davies Black Publishing, Inc.

Sitepu, B. P. (2010). Memimpin organisasi belajar. Diakses dari website http://bintangsitepu.wordpress. com/2010/07/02/memimpin-organisasi-belajar/.

Senge, P.M. (1996). The fifth discipline. The art and practice of the learning organization. Alih Bahasa : Nunuk Adiarni, Lyndon Saputra (ed). Jakarta: Binarupa Aksara

Shelton, K. (ed). (1997). A new paradigm of leadership. Vision of excellence for 21st century organization. Utah: Executive Excellence Publishing

Tilaar, H.A.R. (1995). Paradigma baru pendidikan nasional. Jakarta: Rineka Cipta

Zamroni. (1992). Pengantar pengembangan teori sosial. Yogyakarta: Tiara Wacana 